\title{
Determinants of Causal Ambiguity and Difficulty of Knowledge Transfer within the Firm
}

Ugur Uygur

Loyola University Chicago, uuygur@luc.edu

Follow this and additional works at: https://ecommons.luc.edu/business_facpubs

Part of the Strategic Management Policy Commons

\section{Author Manuscript}

This is a pre-publication author manuscript of the final, published article.

\section{Recommended Citation}

Uygur, Ugur. Determinants of Causal Ambiguity and Difficulty of Knowledge Transfer within the Firm. , , : , 2013. Retrieved from Loyola eCommons, School of Business: Faculty Publications and Other Works,

This Article is brought to you for free and open access by the Faculty Publications and Other Works by Department at Loyola eCommons. It has been accepted for inclusion in School of Business: Faculty Publications and Other Works by an authorized administrator of Loyola eCommons. For more information, please contact ecommons@luc.edu. c) (†) $\ominus$

This work is licensed under a Creative Commons Attribution-Noncommercial-No Derivative Works 3.0 License. (C) eContent Management Pty Ltd, 2013 


\title{
DETERMINANTS OF CAUSAL AMBIGUITY AND \\ DIFFICULTY OF KNOWLEDGE TRANSFER WITHIN THE FIRM
}

\begin{abstract}
The knowledge-based view of the firm portrays knowledge assets as the basis of sustainable competitive advantage. However, leveraging the knowledge available to the firm is not straightforward. The transfer of best practices within the firm or the replication of a certain routine poses challenges for managers. Causal ambiguity of knowledge makes it difficult to transfer practices into other contexts within the firm. In this paper, a new framework is proposed that identifies four antecedents to causal ambiguity: complexity, tacitness, relevance to the existing knowledge base, and the locality of knowledge. The paper concludes with the implications of the framework.
\end{abstract}


This conceptual paper extends the current research on knowledge transfer within the firm (Argote \& Ingram, 2000; Héliot \& Riley, 2010; Szulanski, 1996) by proposing novel explanations of a major impediment to knowledge transfer: causal ambiguity. The ability to transfer knowledge within a firm allows it to replicate practices in other parts of the organization or in other markets. The literature suggests that knowledge transfer can be difficult (Garavelli, Gorgoglione \& Scozzi, 2002; Szulanski, 2000). The focus of this paper is on the attributes of knowledge that cause that difficulty. I build on Simonin's (1999) work on knowledge transfer between two firms by bringing the theoretical conversation inside the firm and contribute two other constructs to the conceptual model. The resulting framework in this paper is a conceptual structure in which the four attributes of knowledge lead to transfer difficulty via the mediating role of causal ambiguity.

When knowledge transfer occurs, an effective practice is replicated by the firm in other contexts or businesses (Helfat \& Eisenhardt, 2004). Transfer of knowledge from one unit in the firm to another is strategically important because it allows the firm to leverage fundamentally important knowledge assets (Zander \& Kogut, 1995). For instance, a detailed case study of Xerox Europe (Jensen \& Szulanski, 2007) showed that knowledge residing in the firm was not fully leveraged; top management identified significant performance differences among the various units conducting similar practices in different European countries and undertook a comprehensive and deliberate effort to transfer knowledge associated with the sales processes. In the units to which knowledge was successfully transferred, sales increased nearly threefold.

The benefits of knowledge transfer within the firm are emphasized in strategy research, particularly in the knowledge-based view. According to this perspective, a given firm’s effectiveness in knowledge transfer has serious consequences for its performance (Zander \& 
Kogut, 1995), and the effective creation and application of knowledge provides the basis of sustainable competitive advantage (Grant, 1996a; Spender \& Grant, 1996). For such firms as McDonald's, Walmart, and Starbucks, the strict replication of existing knowledge in new contexts is the growth strategy (Winter, Szulanski, Ringov \& Jensen, 2012). The most strategically important knowledge is usually complex, tacit, causally ambiguous, and embedded in the operations of the firm (Jensen \& Szulanski, 2012; Nelson \& Winter, 1982; Rivkin, 2000). Managing a firm's knowledge proves to be a different problem than managing any other type of resource, in the traditional sense of the term (Goh, 2002). This is the case because knowledge has unique attributes that make its transfer within the same organization theoretically interesting. In broad terms, most widely studied attributes of knowledge are tacitness and context dependence. Those attributes explain how knowledge differs from mere information and underpin why the information-processing view of the firm ${ }^{1}$ (Arrow, 1974; Galbraith, 1973; Simon, 1957, 1965) cannot answer the knowledge transfer puzzle alone. There is much more to 'what the firm knows' than what is covered by explicit information (Machlup, 1980). Knowledge is not given to anybody in its totality because of the specifics of time and place (Hayek, 1945). Knowledge is also differentiated from information by its inherent tacitness (Polanyi, 1962). Tacitness is not only a problem of knowledge residing in individual minds but also in organizational units. This makes an organization a distributed knowledge system that "lacks the cognitive equivalent of a control room” (Tsoukas, 1996: 22). Therefore, within the firm there will be units that engage in similar practices but with significantly differing results (Chew, Bresnahan \& Clark, 1990; Szulanski, 1996). For instance, a detailed study of steel wire

\footnotetext{
${ }^{1}$ Fransman (1998) provides a detailed comparison of information-processing and knowledge-based views: "Information may be defined as data relating to states of the world and the state-contingent consequences that follow from events in the world that are either naturally or socially caused.” Knowledge is based on information when defined as "justified true belief”; it also involves a
} 
manufacturers with multiple subunits showed that high-performing routines did not disseminate easily to neighboring units (Lapré \& Van Wassenhove, 2003). Some units continued conducting lower-performing routines even when other units in the same organization possessed and demonstrated higher-performing routines. In other words, knowledge is heterogeneously distributed across the organization.

This paper contributes a theoretical model focused on the attributes of knowledge that partially explains the difficulty of knowledge transfer within the firm. Existing research on knowledge transfer identified several sets of reasons that make knowledge "sticky” (Szulanski, 1996). The motivation and willingness of the parties (Héliot \& Riley, 2010), the capabilities of the parties (Chang, Gong \& Peng, 2012), available communication methods (Argote \& Ingram, 2000), contextual organizational structures (Argote, McEvily \& Reagans, 2003; Raman \& Bharadwaj, 2012), and finally attributes of knowledge (Szulanski, 1996; Winter \& Szulanski, 2001) are potential sets of factors that make knowledge transfer within the firm difficult. In this paper, I propose a conceptual structure on the latter set of reasons: the attributes of knowledge. The theoretical model identifies five attributes of knowledge that make its transfer difficult and maps their relationships to each other. Causal ambiguity plays a central, mediating role. The other four reasons make knowledge transfer difficult via their effects on causal ambiguity. The next two sections revisit the literature on the difficulty of knowledge transfer and the central role of causal ambiguity in that process. Then I discuss the four antecedents to causal ambiguity and develop propositions about their relationships to it. The paper concludes with the research and managerial implications of the model. From a practical perspective, if managers know the obstacles to knowledge transfer they can develop tools and mechanisms to overcome them. From 
a theoretical perspective, this critical investigation into the nature of knowledge sheds on how causal ambiguity undermines knowledge transfer.

\section{DIFFICULTIES OF KNOWLEDGE TRANSFER}

According to Grant, the firm's basic function is the application of available knowledge (1996a). Effective management of knowledge flows within the firm provides sharing and transfer of knowledge assets and facilitates new knowledge creation (Nonaka \& Takeuchi, 1995). Kogut and Zander (1992) state that sharing and transfer of knowledge within the firm is more efficient than the replication of the same process through market transactions. Organizations need to leverage their knowledge assets to achieve the greatest possible strategic advantage (Sanchez, 1997). Since firms benefit from leveraging of their knowledge, differentials in this capability in turn lead to differentials in firm performance (Hoopes \& Postrel, 1999). In a competitive environment the benefits of leveraging knowledge assets translates into a competitive pressure that does not apply to other resources in the same manner (Arthur, 1994). Knowledge-based assets demonstrate increasing returns such that they lose value if they are not applied and shared within the firm. Those firms which can leverage their knowledge in other domains and replicate existing practices in other units outperform firms which lack those capabilities (Prahalad \& Hamel, 1990). For all its importance, management researchers maintain that managing knowledge flows within the firm is a challenge (Haas \& Hansen, 2007; Håkanson, 2010; Williams, 2007), and much has been written about why.

Existing literature reflects the wide variety of contexts in which knowledge transfer may occur. There is transfer of knowledge among competitors, which might be described as imitation (Appleyard, 1996; Attewell, 1992; Lippman \& Rumelt, 1982); transfer of knowledge between 
two cooperating firms in the context of strategic alliances and joint ventures (Simonin, 1999); and transfer of knowledge between subunits within a given firm (Szulanski 1996). Not only are the contexts of the transfer but also the analytical structures employed by the researchers not the same. Adding to the conceptual confusion, they examine different causal mechanisms to explain the differences in knowledge transfer in those various contexts. Some studies refer to the basic factors borrowed from information theory to examine the properties of the sender, receiver, channels, and the content of information (e.g., Cohen \& Levinthal, 1990; Hayes \& Fitzgerald, 2009; Leonard-Barton, 1990; Rogers, 1983; Teece, 1977). Others look at cognitive and motivational forces that might influence the willingness and the ability of those involved in the transfer (e.g., Hayes \& Clark, 1985; Héliot \& Riley, 2010; Katz \& Allen, 1982; Perloff, 1993; von Hippel, 1994). A related set of factors is uncovered by looking at the economic incentives that might be affecting the difficulty of transfer. For instance, individuals choose to share their knowledge for reciprocity and reputation effects. They agree to engage in knowledge transfer activities when they believe that it will help their tenure in the organization (Verbeke, Belschak, Bagozzi \& Wuyts, 2011).

The focus of this paper is the attributes of the knowledge, rather than the context or process of transferring it. Existing literature identifies a number of attributes that affect the transferability of knowledge, such as tacitness, causal ambiguity, relevance, carriers of knowledge, and type of knowledge (Winter, 1987; Zander \& Kogut, 1995). Generally, researchers consider how these attributes facilitate or impede knowledge transfer and emphasize the direct effects of these factors. However, in his examination of strategic alliances, Simonin (1999) argues that causal ambiguity plays a mediating role. This paper takes a similar stance in acknowledging the centrality of causal ambiguity in the transfer process within the firm. I 
provide further rationale on the mediating role of complexity and tacitness, and the effects of these factors on causal ambiguity in the transfer process within the firm. As the knowledge being transferred becomes more complex and tacit, causal ambiguity increases, hindering the transfer process. Additionally, two other attributes of knowledge, which influence the ease of transfer through their effect on causal ambiguity, are included in this model: relevance and locality. Both variables are negatively related to causal ambiguity. When knowledge is relevant to the existing knowledge-base of the firm, causal ambiguities related to the particular problems are likely to be resolved in a shorter time. Similarly, when it is possible to locate the crux of knowledge within a small set of individual minds, it will take less effort to resolve causal ambiguity. These factors facilitate the transfer process. Figure 1 depicts the proposed conceptual model which develops a mediating mechanism explained below.

Insert Figure 1 about here

\section{CAUSAL AMBIGUITY}

Causal ambiguity is identified as a fundamental attribute of knowledge in the knowledge transfer literature. Broadly defined, ambiguity refers to a lack of clarity in interpretation and understanding. However, this definition is too generic for our purposes. More specifically, in the context of the knowledge-based view, a particular type of ambiguity gains importance. Within the context of a firm, the knowledge-based view emphasizes a particular lack of clarity in understanding a set of actions which produce a successful business outcome. These repeated sets of actions with certain expected outcomes are the routines of the firm (Nelson \& Winter, 1982). Because of uncertainty and the collective nature of the routines, not all causal relationships between the actions and their outcomes are clear (Lippman \& Rumelt, 1982). Firms might be 
able to perform tasks relatively effectively, but that does not necessarily mean that the impact of a given action is known completely by the actors or observable to an outsider (Lakshman, 2011; Williams, 2007). Accordingly, causal ambiguity is defined as the lack of understanding of the linkages between actions and their results in this context (Lippman \& Rumelt, 1982; Ambrosini \& Bowman, 2010).

Previous research postulates a negative relationship between the degree of causal ambiguity and the transferability of knowledge. For example, Szulanski (1996) proposed that causal ambiguity would increase the eventfulness of transfer especially in the initial stages of the process. Eventfulness is Szulanski’s measure of difficulty; when knowledge transfer does not proceed as expected, the participants note problems and the process is classified as eventful. In his results, causal ambiguity proved to significantly impact eventfulness in all stages of the knowledge transfer process. Similarly, Simonin (1999) shows that it is harder to transfer causally ambiguous knowledge in a strategic alliance context. This yields the following proposition, depicted in Figure 1:

Proposition 1. Causal ambiguity of knowledge is positively related to the difficulty of its transfer.

\section{COMPLEXITY}

The complexity of knowledge is defined as the magnitude of interactions among the components of a specific knowledge asset. As the number of distinguishable pieces and their interactions within the knowledge increase, it becomes more complex. This increases ambiguity simply because the sheer number of possible alternative causal models will increase, and it will be more difficult to tell which action produced which result. The effect of complexity on knowledge transfer is as expected. Some researchers construct a direct link between the inherent 
complexity of knowledge and its transferability (e.g., Smith \& Zeithaml, 1996). Rivkin (2001) states that the more complex the knowledge, the harder it is to replicate. Similarly Kogut and Zander (1992) propose that the ease of transfer decreases with increasing complexity. And finally Hansen (1999) argues that complexity requires stronger ties between communicating parties in order to facilitate transfer. The connection between complexity and what we can loosely term transfer difficulty relies, however, on a mediating factor.

A close reading of the literature suggests that complexity makes it difficult for the knowledge to be transferred because it makes the causal connections hard to decipher. Complex knowledge is hard to transfer because that knowledge is more likely to be causally ambiguous to the parties. In a different context, Reed and DeFillippi (1990) construct a similar link between causal ambiguity and the complexity of firm strategies. They argue that complexity is a factor that leads to causally ambiguous competencies. Following their model, Simonin (1999) demonstrates the existence of the correlation between complexity and causal ambiguity. Applying this model to the transfer of knowledge within the firm yields the following proposition depicted in Figure 1:

Proposition 2. Complexity is positively related to the degree of causal ambiguity of knowledge.

\section{TACITNESS}

In management studies, Polanyi (1962) was the first to introduce the idea that individuals are capable of more than what they can tell. Tacitness refers to the aspect of knowledge that is not articulated ${ }^{2}$, and it has been widely studied in terms of its effects on knowledge transfer. A measure of tacitness, the degree of codification is related to the speed and the ease of transfer 
(Zander \& Kogut, 1995). The effect of codification to help alleviate that difficulty is also shown in a study of an Italian industrial district by Albino, Garavelli, and Schiuma (1998). In their analysis of international joint ventures Inkpen and Dinur (1998) also propose that tacitness makes it harder to transfer knowledge. In the context of acquisitions, a similar effect is proposed as well: tacit knowledge is more difficult to be appropriated by the acquiring firm (Bresman, Birkinshaw, \& Nobel, 1999). And finally, in the case of entrepreneurial firms Knockaert, et al. (2011) propose that tacitness impedes knowledge transfer.

Similar to the discussion above, the mechanism that links tacitness with the ease of transfer involves causal ambiguity as a central phenomenon (Reed \& DeFillippi, 1990). Those previous studies mentioned above explain the connection between tacitness and the difficulty of transfer via the lack of understanding of causal connections. If knowledge is tacitly stored in the individual or the collective mind ${ }^{3}$, then the causal relationships among particular actions and their results are less likely to be identified. The portion of knowledge that might explain why a certain practice leads to successful results is more likely to be overlooked or misunderstood. That means the causal ambiguity associated with that particular practice will be greater, and consequently its transfer will be harder. This yields the following proposition depicted in Figure 1:

Proposition 3. Tacitness is positively related to the degree of causal ambiguity of knowledge.

\footnotetext{
2 The term tacit knowledge is also used to describe that which is impossible to articulate. However, many others believe that any valuable knowledge can be articulated with time and effort.

${ }^{3}$ It is claimed that all tacit knowledge is stored in individual minds and the phrase "collective mind" is at best a metaphor that does not correspond to reality (see Spender, 1998, for an account of the "collective mind"). This distinction is irrelevant for the purposes of this paper, since tacitness will be related to causal ambiguity regardless of the location of tacit knowledge.
} 


\section{RELEVANCE TO EXISTING KNOWLEDGE BASE}

Tsoukas’s (1996) work on organizational knowledge demonstrates that it is not possible to localize knowledge and draw its boundaries within a part of the organization. Organizational knowledge is dispersed and collective. This observation leads to another factor that will influence the process of knowledge transfer. Because of the dispersed nature of knowledge, the particular practice to be transferred will be shared to varying degrees by the rest of the organization. The unit that has access to knowledge will make use of the preexisting knowledge base provided by the organization. The overlap might be of varying degrees and will help the transfer of knowledge by providing a similar collective cognitive base ${ }^{4}$.

The broader idea that preexisting knowledge influences the adoption of new knowledge is not a novel one (e.g., Cohen \& Levinthal, 1990). For example, Presutti, Boari, and Majocchi (2011) found that cognitive proximity increases the likelihood of knowledge transfer within startups. Teece (1977) found that previous experience with a technology reduced the costs of transferring new knowledge about it. This might be explained by the relevance of the new knowledge to the firm’s preexisting knowledge. Schulz (2001) argues that the newer the knowledge, the more intense the vertical outflows (between subsidiary and headquarters). This finding supports the necessity of aligning unit knowledge with the existing knowledge base in the rest of the firm ${ }^{5}$. Furthermore, Szulanski (1996) argues that unproven knowledge is difficult to transfer. This too might be explained by a lack of relevance to the existing knowledge base,

\footnotetext{
${ }^{4}$ Because the firm lacks a cognitive control room, the managers of the firm do not know everything the firm knows. This is true even when subunits within the firm are considered. In this discussion of the relevance construct, the knowledge base is not conceptualized objectively but instead thought of subjectively as perceived by the subunit. In other words, the relevance construct does not capture what the managers should have experienced if they knew what they knew. Instead, the relevance construct captures what the managers will experience given their level of awareness. I thank an anonymous reviewer for raising this difference.

${ }^{5}$ Hierarchical structure is a means to economize on knowledge requirements (Spender, 1996; Tsoukas, 1996), which is a justification for the existence of the firm. When a subunit acquires new knowledge, the need to integrate this new knowledge will
} 
since provenness is a function of applying existing proven practices. Simonin’s (1999) finding that experience with a practice is negatively related to ambiguity can be explained using the same rationale. In their analysis of Swedish multinationals, Birkinshaw, Nobel, and Ridderstrale (2002) show that the system-embeddedness of knowledge has an effect on organizational structure. Their conception of system-embeddedness suggests that “some knowledge is much more sensitive to its social and physical context than other knowledge” (Birkinshaw, Nobel, \& Ridderstrale, 2002: 278).

Relying on the information processing perspective, Huber (1991) proposes that relevance to the receiver's knowledge would positively influence the ease of transfer of information. However, Szulanski (2000) found a surprising result: that preexisting knowledge slowed down the transfer process due to the need for unlearning. Simply having access to related knowledge did not help with the transfer process; the receiving unit had to "forget" preexisting knowledge in order for new knowledge to be successfully transferred (Cegarro-Navarro, Eldridge \& Sánchez, 2012). On its face, this appears to contradict the idea that relevance eases transfer, but it is not merely knowing about similar phenomena, but having similar solutions for relevant problems that counts as having relevant knowledge. Otherwise, the causal ambiguity perceived by the receiving unit might intensify if the new knowledge is inconsistent with the existing practices.

Another related argument is made about asset-specificity, a concept borrowed from Williamson (1985). Reed and DeFillippi (1990), and then Simonin (1999), argue that specificity leads to causal ambiguity because the knowledge emerging from transaction-specific assets will remain ambiguous to competitors. But their reasoning can only explain ambiguity as perceived by a competitor; this might be a barrier to imitation, but not other types of transfer, of the 
transaction-specific knowledge. As convincingly argued by Williamson, it is understandable that transaction-specific knowledge arises in certain circumstances and its transfer is difficult to negotiate. However, it is unclear from this perspective why transaction-specific knowledge will be ambiguous to the very firm using it. Not surprisingly, in Simonin’s (1999) empirical analysis, asset specificity turned out to be insignificant to ambiguity. I propose that the lack of support in his study can be explained by the relevance construct in this model. Asset specificity makes transfer difficult if the knowledge created and applied is not closely related to the firm's preexisting knowledge base. Transaction specificity per se does not mean that the practice associated with the particular assets is irrelevant to the existing knowledge base of the firm. It is the specificity of the knowledge rather than other assets, which is captured by the idea of relevance to the existing knowledge base. This yields the following proposition depicted in Figure 1:

Proposition 4. The relevance to the existing knowledge base is negatively related to the degree of causal ambiguity of knowledge.

\section{LOCALITY OF KNOWLEDGE}

From Nelson and Winter (1982) to Nonaka and Takeuchi (1995), many researchers have acknowledged the importance of the type of carrier in which knowledge resides. Basically, they identify four different carriers: individual, group, organization, and network. Tsoukas (1996) has stated that it is not possible to fully localize any knowledge used by an organization. In his study of new product development, Carlile (2002) shows that the location of the knowledge matters. As a critique of the capabilities-based view, Felin and Hesterly (2007) maintain that knowledge 
resides mainly in individuals. However, strategic management research convincingly demonstrates that there are various possibilities along a continuum from one to many carriers: a practice might be best encapsulated within an individual mind, or a team, or the involvement of a whole subunit might be necessary to cover the bulk of knowledge to be transferred.

Inkpen and Dinur (1998) found a positive relationship between the difficulty of transfer and the number of the carriers of knowledge. Similarly, Argote and Ingram (2000) argue, knowledge embedded in all possible carriers (i.e., people, tasks, and tools) is harder to transfer than knowledge that is embedded in a single carrier. Knockaert et al. (2011) propose that the human resources might need to be relocated for knowledge to be transferred effectively. In a recent empirical study, Gardner, Gino, and Staats (2012) find that the previous relationships among team members have an effect on how their knowledge is brought together. I propose that causal ambiguity mediates this effect. The task of linking actions with results to reduce causal ambiguity becomes harder as one moves from a smaller set of carrier minds to a larger set, because of the increased dispersion of knowledge. Accordingly, the transfer will be harder. If knowledge is located in an individual mind rather than a team of individuals, it will present less causal ambiguity since all individual-specific hazards will already exist in the team with the addition of group cognition dynamics ${ }^{6}$. By the same token, enlarging the locality to the subunit level will make the ambiguity more severe. This yields the following proposition depicted in Figure 1:

\section{Proposition 5. Locality of knowledge is negatively related to the degree of causal ambiguity of knowledge.}

\footnotetext{
${ }^{6}$ I assume that the team does not have a hundred percent redundancy, in which everybody knows everything about the practice. In such a case, causal ambiguities might be better resolved since more than one mind would have access to the same knowledge. The arguments above assume a team with a division of labor, or specialization, which leads to dispersedness and partitioning of knowledge.
} 


\section{IMPLICATIONS FOR RESEARCH AND FUTURE DIRECTIONS}

The theoretical model in this paper advances a framework that rests on the following premise: something unique about the nature of the knowledge makes its transfer difficult inside a firm and there is a structure to this difficulty. Consistent with the previous literature I maintain that complexity and tacitness are two critical attributes of knowledge in the context of transfer. Additionally, I advocate two new constructs: relevance and locality. When knowledge is complex, tacit, not relevant to the receiving unit's knowledge base, and not locally identifiable within a small group of people, it is more difficult to transfer. As importantly, the framework advances a meditation structure. I argue that causal ambiguity (Reed \& DeFillippi, 1990; Simonin, 1999) plays a central role. All four antecedents make knowledge transfer difficult because they make the knowledge more causally ambiguous.

The theoretical development in this paper is intended to shed some light on the question “why do organizations not know what they know?” By comprehending some possible sources of causal ambiguity, researchers might be better equipped to understand not only causal ambiguity in general but also the knowledge transfer process. The framework proposed in this paper might aid understanding of the impediments to leveraging of knowledge assets within the firm, identified by researchers (Guzman \& Wilson, 2005; Kogut \& Zander, 1993; Spender \& Grant, 1996; Tsoukas, 1996) as a fundamental function of organizations.

The arguments in this paper, especially those related to the relevance of knowledge to the existing knowledge base, apply Tsoukas’ (1996) observation of the dispersed nature of knowledge in the firm. The issues identified by Becker (2001) in this respect are also shown to be effective in the context of knowledge transfer. Depending on the dispersion of knowledge, it 
is argued that the causal ambiguity of a particular practice is more likely to be addressed and resolved when subunits (especially those that are vertically linked) share knowledge.

The central treatment of causal ambiguity and the two new attributes of knowledge proposed in this framework have implications for the theory of the firm ${ }^{7}$. According to the knowledge-based view, firms exist in order to integrate specialized knowledge (Grant, 1996b) and replicate it across space and time (Nelson \& Winter, 1982; Kogut \& Zander, 1992). They provide efficiencies over market transactions by providing a common identity and knowledge base across the organization that allows the firm to exploit similar opportunities in new contexts (Dyer \& Nobeoka, 2000; Håkanson, 2010; Kogut \& Zander, 1996). The relevance construct advanced in this model provides an explanation for this advantage and simultaneously points to its theoretical limits. As long as the firm's common knowledge-base is able to provide the receiving units with relevant knowledge, transfer of new knowledge will be easier within the firm than between firms. On the flip side, this suggests path dependence story in which valuable but less relevant knowledge will be perceived as causally ambiguous by the receiving parties. This will limit the leveraging of such "deviant” knowledge assets inside the firm and favor market solutions for solving the problems those knowledge asserts pertain to.

Similarly, the other novel attribute, locality, has implications for the scope of a firm. When knowledge is transferred from one unit to another within the organization, the firm can make better use of its resources. Penrose (1959) asserts that managers' imaginations of how the resources can be used are the main impetus for firm growth. Imagining the services obtainable from the resources on hand is the result of a process that takes the knowledge-base of the organization as its basic input. However the theoretical development in this paper points to some

\footnotetext{
${ }^{7}$ I thank two anonymous reviewers for the insight.
} 
knowledge-based limits to the growth of the firm. If the unique knowledge the firm wants to replicate and exploit is encapsulated within a small group, the firm will be in a favorable position to grow internally. But as the firm grows, the dispersion of knowledge also grows (Tsoukas, 1996); knowledge resides, instead of merely in key individuals, in teams and organizational routines. When this happens, causal ambiguity associated with the knowledge increases, thereby making the firm hierarchy less efficient at replicating key practices.

Previous literature identified three broad categories of factors that might affect difficulty in transferring knowledge within the firm. First, cognitive and psychological factors are related to perceptual problems and motivational dispositions. An alternative conception of these categories is to think of them as the capability of transferring and the willingness to transfer (Héliot \& Riley, 2010; Wang, Tong \& Koh, 2003). Economic incentives are the second category that will influence the willingness of the parties in the process of transfer. Finally, factors that are about the nature of the knowledge itself include those that are studied in the scope of this paper. There is a need to study the effects of these factors simultaneously. Szulanski (1996) studied a subset of these constructs and found that knowledge attributes affected transfer more significantly than motivational aspects. More empirical evidence is needed in order to understand the relative importance of the factors. It is also probable that there is a moderating relationship among these categories of factors—-for instance, high willingness in the receiving unit might make even nonrelevant information easier to transfer by alleviating causal ambiguity. More empirical evidence is needed about the relationships between and relative importance of the factors.

While knowledge can also be transferred between organizations (e.g., Bojica, Fuentes \& Gómez-Gras, 2011), in this paper the scope of the conceptual model is limited to the focal firm 
and the transfers within. An often-repeated concern in the literature (Reed \& DeFillippi, 1990; Badaracco, 1991; Kogut \& Zander, 1995; King \& Zeithaml, 2001; Rivkin, 2001) is the possibility that ease of transfer might mean ease of imitation. A fruitful avenue of research might be to look at the role of the constructs used in this study and the mediating effect of causal ambiguity. However, the relationships are not so straightforward when one considers the threat of imitation. For example, Rivkin (2001) proposed an equilibrium effect in which the distance between the threat of imitation and ease of transfer is at a maximum. Therefore, moderate levels of complexity were considered preferable to other levels. However, the relevance of new information to a focal firm's knowledge base may protect it from this vulnerability, perhaps even increasing its advantage over imitators as new knowledge gets more integrated with the existing knowledge-base. For this construct, moderate levels might not be the optimal choice.

The interactions among independent variables also need examination. The knowledge attributes discussed in this study might not be orthogonal to each other under all circumstances. For example, the difficulties caused by the complexity of knowledge might be alleviated by strong relevance. In that case, the effect of complexity might be reduced for those practices that are highly ingrained with the supervising unit that facilitates the transfer. Similar effects may be discovered among the independent variables above.

\section{MANAGERIAL IMPLICATIONS}

This research identifies some of the factors that need to be taken into account by the managers who are responsible for transferring and replicating practices within the firm (see Argote, 1999 for examples). All of the factors outlined above are amenable to managerial action that will influence the perception of causal ambiguity associated with knowledge. For instance, a focus group of practicing knowledge managers found that tacit knowledge was especially hard to 
transfer (Smith, McKeen \& Singh, 2007). Tacit components of knowledge might be manipulated by further codification and appropriate use of knowledge management tools, perhaps decreasing its effect on causal ambiguity and enhancing the transfer process.

Another managerial implication is the correct specification of the problems by showing possible sources of causal ambiguity. Transfer of knowledge is a complicated process (Szulanski, 1996). Managers may find it hard to track down the sources of difficulties they face throughout the process. Demonstrating the effects of the four constructs may assist managers in identifying the possible reasons for problems and point out potentially different solutions. For instance, difficulties related to complexity of the practice will require different solutions than those related to tacitness, although both might be observed as causal ambiguity of the practice without proper analytical reasoning. Current literature, especially knowledge management discussions, focuses on codification solutions for knowledge ambiguity and its capture. Reading of current managerial literature might lead to extensive use of codification techniques wherever ambiguity creates problems for transfer. Codification, however, is not a universal solution to knowledge transfer difficulties (Haas \& Hansen, 2007). This paper argues that other factors increase causal ambiguity associated with knowledge. Solutions that pertain to only one factor might not be helpful when other factors are influential.

\section{CONCLUSION}

Knowledge-based perspectives point out intangible assets of the firm that can be used for sustainable competitive advantage (Watson \& Hewett, 2006). Knowledge transfer has been shown to be a challenging process with unique difficulties (Szulanski, 2000). But there is economic pressure on the firm to leverage its knowledge and foster transfer of best practices (Grant, 1996b; Kogut \& Zander, 1993). Managers need to know what factors play significant 
roles in the transfer process. In addition to cognitive, psychological, and economic factors, knowledge attributes are also influential in the success of the transfer. Relying on Reed and DeFillippi (1990), Simonin (1999) proposes that complexity and tacitness of the knowledge are two attributes that influence causal ambiguity associated with the knowledge. In turn, causal ambiguity poses difficulties to the transfer process.

In addition to further elaboration of these linkages, this paper proposes two more factors (relevance and locality) that influence the causal ambiguity of knowledge. When the transferred knowledge is more relevant to the existing knowledge-base of the firm and when the transferred knowledge resides in a smaller set of locations, the process gets less cumbersome. Empirical testing of these propositions will further complement the existing literature and help managers to identify and solve problems in transfer and replication. 


\section{REFERENCES}

Albino, V., Garavelli, A. C., \& Schiuma, G. (1998). Knowledge transfer and inter-firm relationships in industrial districts: the role of the leader firm. Technovation, 19, 53-63.

Ambrosini, V., \& Bowman, C. (2010). The impact of causal ambiguity on competitive advantage and rent appropriation. British Journal of Management, 21, 939-953.

Appleyard, M. M. (1996). How does knowledge flow? Interfirm patterns in the semiconductor industry. Strategic Management Journal, Winter Special Issue, 17, 137-154.

Argote, L. (1999). Organizational Learning: Creating, Retaining and Transferring Knowledge. Boston: Kluwer Academic Publishers.

Argote, L., \& Ingram, P.( 2000). Knowledge transfer: a basis for competitive advantage in firms. Organizational Behavior and Human Decision Processes, 82,150-169.

Argote, L., McEvily, B., \& Reagans, R. (2003). Managing knowledge in organizations: An integrative framework and review of emerging themes. Management Science, 49, 571582.

Arrow, K. (1974). The Limits of Organization. New York: W.W. Norton.

Arthur, W. B. (1994). Increasing Returns and Path Dependency in the Economy. Ann Arbor: University of Michigan Press.

Attewell, P. (1992). Technology diffusion and organizational learning: the case of business computing. Organization Science, 3, 1-19.

Badaracco, J. L. (1991). The Knowledge Link. Boston: Harvard Business School Press.

Becker, M. C. (2001. Managing dispersed knowledge: organizational problems, managerial strategies, and their effectiveness. Journal of Management Studies, 38,1037-1051. 
Birkinshaw, J., Nobel, R., \& Ridderstrale, J. (2002). Knowledge as a contingency variable: do the characteristics of knowledge predict organization structure. Organization Science, 13, 274-289.

Bojica, A. M., Fuentes, M. D. M., \& Gómez-Gras, J. M. (2011). Radical and incremental entrepreneurial orientation: the effect of knowledge acquisition. Journal of Management \& Organization, 17, 326-343.

Bresman, H., Birkinshaw, J., \& Robert, N. (1999). Knowledge transfer in international acquisitions. Journal of International Business Studies, 30: 439-462.

Carlile, P. C. (2002). A pragmatic view of knowledge and boundaries: boundary objects in new product development. Organization Science, 13, 442-455.

Cegarro-Navarro, J. G., Eldridge S., \& Sánchez, A. L. G. (2012). How an unlearning context can help managers overcome the negative effects of counter-knowledge. Journal of Management \& Organization, 18, 231-246.

Chang, Y., Gong, Y., \& Peng, M. W. (2012). Expatriate knowledge transfer, subsidiary absorptive capacity, and subsidiary performance. Academy of Management Journal, 55, 927-948.

Chew, W. B., Clark, K. B., \& Bresnahan, T. (1990). Measurement, coordination and learning in a multi-plant network. In R. S. Kaplan (Ed.), Measures for Manufacturing Excellence. Boston: Harvard Business School Press.

Cohen, W. M., \& Levinthal, D. (1990). Absorptive capacity: a new perspective on learning and innovation. Administrative Science Quarterly, 35, 128-152.

Dyer, J. H., \& Nobeoka, K. (2000). Creating and managing a high-performance knowledgesharing network: The Toyota case. Strategic Management Journal, 21, 345-367. 
Felin, T., \& Hesterley, W.S. (2007). The knowledge-based view, nested heterogeneity, and the new creation: philosophical considerations on the locus of knowledge. Academy of Management Review, 32, 195-218.

Fransman, M. (1994). Information, knowledge, vision and theories of the firm. Industrial and Corporate Change, 3, 713-757.

Galbraith, J. R. (1973). Designing Complex Organizations. Reading, MA: Addison-Wesley.

Garavelli, A. C., Gorgoglione, M., \& Scozzi, B. (2002). Managing knowledge transfer by knowledge technologies. Technovation, 22, 269-279.

Gardner, H. K., Gino, F., \& Staats, B. R. (2012). Dynamically integrating knowledge in teams: transforming resources into performance. Academy of Management Journal, 55, 9981022.

Goh, S. C. (2002). Managing effective knowledge transfer: an integrative framework and some practice implications. Journal of Knowledge Management, 6, 23-30.

Grant, R. M. (1996a). Toward a knowledge-based theory of the firm. Strategic Management Journal, 17(Winter Special Issue), 109-122.

Grant, R. M. (1996b). Prospering in dynamically-competitive environments: organizational capability as knowledge integration. Organization Science, 7(4), 375-387.

Guzman, G., \& Wilson, J. (2005. The soft dimension of organizational knowledge transfer. Journal of Management Knowledge, 9, 59-74.

Haas, M. R., \& Hansen, M. T. (2007). Different knowledge, different benefits: toward a productivity perspective on knowledge sharing in organizations. Strategic Management Journal, 28, 1133-1153. 
Håkanson, L. (2010). The firm as an epistemic community: the knowledge-based view revisited. Industrial and Corporate Change, 19, 1801-1828.

Hansen, M. T. (1999). The search-transfer problem: The role of weak ties in sharing knowledge across organization subunits. Administrative Science Quarterly, 44, 82-111.

Hayek, F. A. (1945). The use of knowledge in society. American Economic Review, 35, 519-530.

Hayes, R. H., \& Clark, K. B. (1985). Exploring the sources of Productivity Differences at the Factory Level. New York: Wiley.

Hayes, K. J \& Fitzgerald, J. A. (2009). Managing occupational boundaries to improve innovation outcomes in industry-research organizations. Journal of Management \& Organization, $15,423-437$.

Helfat, C. E., \& Eisenhardt, K. M. (2004). Inter-temporal economies of scope, organizational modularity, and the dynamics of diversification. Strategic Management Journal, 25, 1217-1232.

Héliot, Y., \& Riley, M. (2010). A study of indicators of willingness in the knowledge transfer process. Journal of Management \& Organization, 16, 399-410.

Hoopes, D. G., \& Postrel, S. (1999). Shared knowledge, glitches, and product development performance. Strategic Management Journal, 20, 837-865.

Huber, G. P. (1991). Organizational learning: the contributing processes and the literatures. Organization Science, 2, 88-115.

Inkpen, A. C., \& Dinur, A. (1998). Knowledge management processes and international joint ventures. Organization Science, 9, 454-468.

Jensen, R. J., \& Szulanski, G. (2007). Template use and the effectiveness of knowledge transfer. Management Science, 53, 1716-1730. 
Katz, R., \& Allen, T. J. (1982). Investigating the Not Invented Here (NIH) syndrome: a look at the performance, tenure, and communication patterns of $50 \mathrm{R} \& \mathrm{D}$ Project Groups. $R \& D$ Management, 12, 7-19.

King, A. W., \& Zeithaml, C. P. (2001). Competencies and firm performance: examining the causal ambiguity paradox. Strategic Management Journal, 22, 75-99.

Knockaert, M., Ucbasaran, D., Wright, M., \& Clarysse, B. (2011). The relationship between knowledge transfer, top management team composition, and performance: the case of science-based entrepreneurial firms. Entrepreneurship Theory and Practice, 35, 777-803.

Kogut, B., \& Zander, U. (1992). Knowledge of the firm, combinative capabilities, and the replication of technology. Organization Science, 3, 383-397.

Kogut, B., \& Zander, U. (1993). Knowledge of the firm and the evolutionary theory of the multinational corporation. Journal of International Business Studies, 24, 625-645.

Kogut, B., \& Zander, U. (1996). What firms do? Coordination, identity, and learning. Organization Science, 7, 502-518.

Lakshman, C. (2011). Postacquisition cultural integration in mergers \& acquisitions: a knowledge-based approach. Human Resource Management. 50, 605-623.

Lapré, M. A., \& Van Wassenhove, L. N. (2003). Managing learning curves in factories by creating and transferring knowledge. California Management Review, 46, 53-71.

Leonard-Barton, D. (1990). The intraorganizational environment: point-to-point versus diffusion. In F. Williams and D. V. Gibson (Eds.), Technology Transfer: A Communication Perspective (pp. 43-62). London: Sage.

Lippman, S. A., \& Rumelt, R. P. (1982). Uncertain imitability: an analysis of interfirm differences in efficiency under competition. The Bell Journal of Economics, 13, 418-438. 
Machlup, F. (1980). Knowledge: Its Creation, Distribution, and Economic Significance. New Jersey: Princeton University Press.

Nelson, R., \& Winter, S. (1982). An Evolutionary Theory of Economic Change. Cambridge, MA: Belknap Press.

Nonaka, I., \& Takeuchi, H. (1995). The Knowledge Creating Company. Oxford, England: Oxford University Press.

Penrose, E. T. (1959). The Theory of the Growth of the Firm. Oxford, England: Basil Blackwell.

Perloff, R. M. (1993). The Dynamics of Persuasion. Hillsdale, NJ: Erlbaum.

Polanyi, M. (1962). Personal Knowledge: Towards a Post-Critical Philosophy (corrected ed.). Chicago: University of Chicago Press.

Prahalad, C. K., \& Hamel, G. (1990). The core competence of the corporation. Harvard Business Review, 68(3), 79-91.

Presutti, M., Boari, C., \& Majocchi, A. (2011). The importance of proximity for the start-ups' knowledge acquisition and exploitation. Journal of Small Business Management, 49, 361389.

Raman, R., \& Bharadwaj, A. (2012). Power differentials and performative deviation paths in practice transfer: the case of evidence-based medicine. Organization Science, 23, 15931621.

Reed, R., \& DeFillippi, R. J. (1990). Causal ambiguity, barriers to imitation, and sustainable competitive advantage. Academy of Management Review, 15, 88-102.

Rivkin, J. W. (2000). Imitation of complex strategies. Management Science, 46, 824-844.

Rivkin, J. W. (2001). Reproducing knowledge: replication without imitation at moderate complexity. Organization Science, 12, 274-293. 
Rogers, E. (1983). The Diffusion of Innovation. New York: Free Press.

Sanchez, R. (1997). Managing articulated knowledge in competence-based competition. In R. Sanchez, A. Heene (Eds.), Strategic Learning and Knoledge Management (pp. 163-187). England: John Wiley and Sons.

Schulz, M. (2001). The uncertain relevance of newness: Organizational learning and knowledge flows. Academy of Management Journal, 44, 661-681.

Simon, H. A. (1957). Administrative Behavior: A Study of Decision-making Processes in Administrative Organization (3rd ed.). New York: Free Press.

Simon, H. A. (1965). The architecture of complexity. In L. von Bertalanffy and A. Rapaport (Eds.), General Systems Yearbook: Yearbook of the Society for General Systems, 10 (pp. 63-76). Ann Arbor, MI: Braun-Brumfeld.

Simonin, B. L. (1999). Ambiguity and the process of knowledge transfer in strategic alliances. Strategic Management Journal, 20, 595-623.

Smith H.A., McKeen J.D., \& Singh S. (2007). Tacit knowledge transfer; making it happen. Journal of Information Science \& Technology, 4(2), 23-44.

Smith, A. D., \& Zeithaml, C. (1996). Garbage cans and advancing hypercompetition: the creation and exploitation of new capabilities and strategic flexibility in two regional Bell operating companies. Organization Science, 7, 383-399.

Spender, J.C. (1996). Making knowledge the basis of a dynamic theory of the firm. Strategic Management Journal, 17 (Winter Special Issue), 45-62.

Spender, J.C. (1998). The dynamics of individual and organizational knowledge. In C. Eden and J. C. Spender (Eds.), Managerial and Organizational Cognition - Theory, Methods and Research. London: SAGE Publications. 
Spender, J.C., \& Grant, R. M. (1996). Knowledge and the firm: overview. Strategic Management Journal, 17 (Winter Special Issue), 5-9.

Subramaniam, M., \& Venkatraman, N. (2001). Determinants of transnational new product development capability: testing the influence of transferring and deploying tacit overseas knowledge. Strategic Management Journal, 22, 359-378.

Szulanski, G. (1996). Exploring internal stickiness: impediments to the transfer of best practice within the firm. Strategic Management Journal, 17(Winter Special Issue), 27-43.

Szulanski, G. (2000). The process of knowledge transfer: a diachronic analysis of stickiness. Organizational Behavior and Human Decision Processes, 82, 9-27.

Teece, D. (1977). Technology transfer by multinational firms: the resource cost of international technology transfer. Economic Journal, 87, 242-261.

Tsoukas, H. (1996). The firm as a distributed knowledge system: a constructionist approach. Strategic Management Journal, 17(Winter Special Issue), 11-25.

Verbeke, W., Belschak, F. D., Bagozzi, R. P., \& Wuyts, S. (2011). Gaining access to intrafirm knowledge: an internal market perspective on knowledge sharing. Human Performance, 24, 205-230.

von Hippel, E. (1994). ‘Sticky information’ and the locus of problem solving: implications for innovation. Management Science, 40, 429-439.

Wang, P., Tong, T.W., \& Koh, C.P. (2004). An integrated model of knowledge transfer from MNC parent to China subsidiary. Journal of World Business, 39, 168-182.

Watson, S., \& Hewett, K. (2006). A multi-theoretical model of knowledge transfer in organizations: determinants of knowledge contribution and knowledge reuse. Journal of Management Studies, 43, 141-173. 
Williams, C. (2007). Transfer in context: replication and adaptation in knowledge transfer relationships. Strategic Management Journal, 28, 867-889.

Williamson, O. (1985). The Economic Institutions of Capitalism: Firms, Markets, Relational Contracting. New York: Free Press.

Winter, S. G. (1987). Knowledge and competence as strategic assets. In D. Teece (Ed.), The Competitive Challenge: Strategies for Industrial Innovation and Renewal (pp. 159-184). Cambridge, MA: Ballinger.

Winter, S. G., \& Szulanski, G. (2001). Replication as strategy. Organization Science, 12, 730743.

Winter, S. G., Szulanski, G., Ringov, D., \& Jensen, R. J. (2012). Reproducing knowledge: inaccurate replication and failure in franchise organizations. Organization Science, 23, 672-685.

Zander, U., \& Kogut, B. (1995). Knowledge and the speed of the transfer and imitation of organizational capabilities: an empirical test. Organization Science, 6, 76-92. 
FIGURE 1

Conceptual Model: Determinants of Causal Ambiguity and Difficulty of Knowledge Transfer

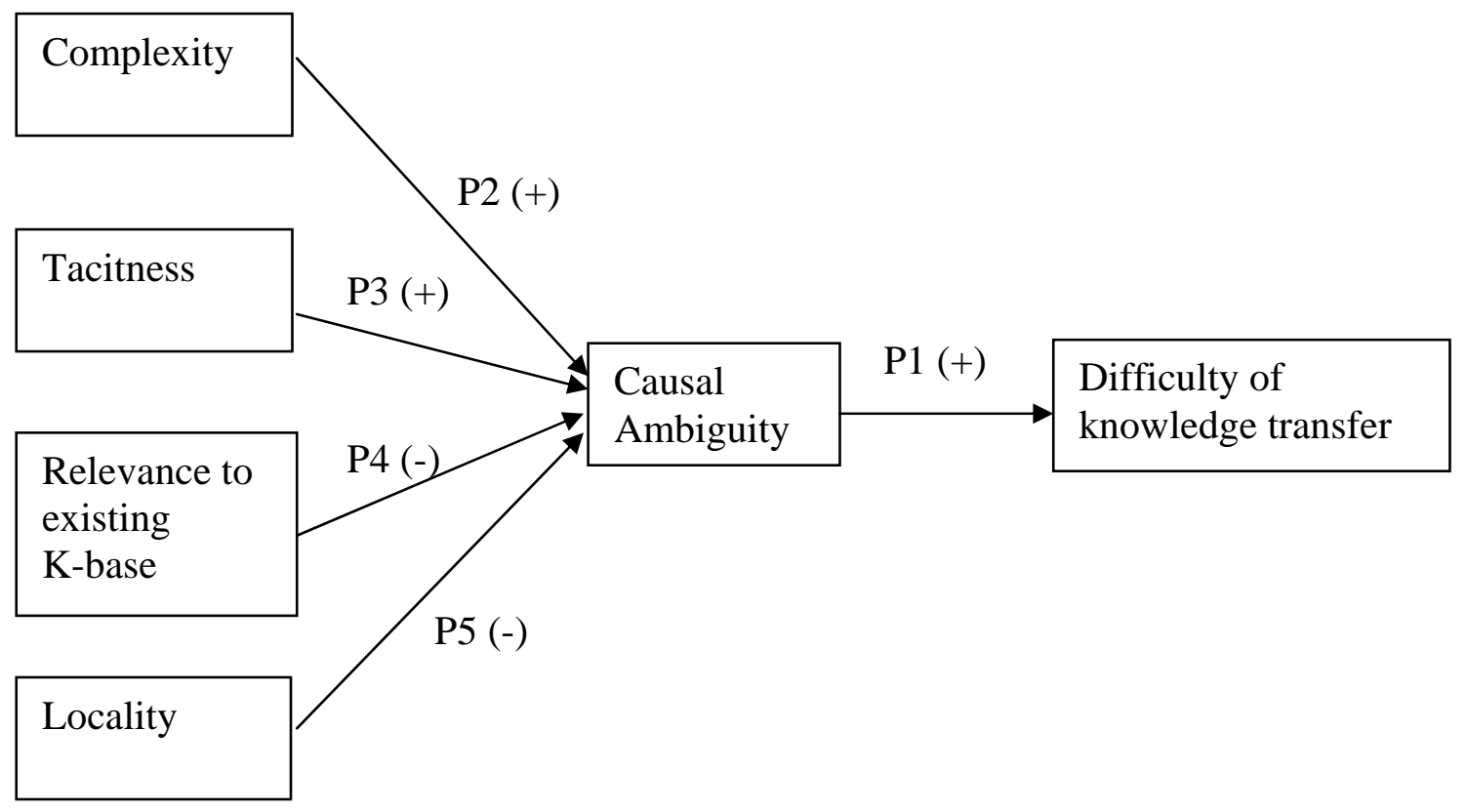

